\title{
The association between ATM D1853N polymorphism and breast cancer susceptibility: a meta-analysis
}

\author{
Lin-Bo Gao ${ }^{1 \dagger}$, Xin-Min Pan ${ }^{2,3+}$, Hong Sun ${ }^{4}$, Xia Wang ${ }^{1}$, Li Rao ${ }^{5}$, Li-Juan Li ${ }^{3}$, Wei-Bo Liang ${ }^{3}$, Mei-Li Lv ${ }^{4}$, \\ Wen-Zhong Yang ${ }^{6}$, Lin Zhang ${ }^{1 *}$
}

\begin{abstract}
Background: Emerging evidence suggests that ataxia telangiectasia-mutated (ATM) is involved in numerous damage repair signaling pathways and cell-cycle checkpoints. Heterozygous carriers of ATM-mutations have an increased risk for the development of breast cancer. The purpose of this study is to evaluate the association between ATM exon39 5557G > A (D1853N, rs1801516) polymorphism and breast cancer susceptibility with the use of a meta-analysis.
\end{abstract}

Methods: By searching PubMed and Embase databases, a total of 9 epidemiological studies with 4,191 cases and 3,780 controls were identified. Crude odds ratios (ORs) and their corresponding 95\% confidence intervals (Cls) for ATM D1853N polymorphism and breast cancer risk were calculated using fixed- or random-effects model based on the degree of heterogeneity among studies.

Results: No significant association between the ATM D1853N polymorphism and breast cancer risk was observed in overall analysis (GA versus GG: $\mathrm{OR}=1.18$; $95 \% \mathrm{Cl}, 0.90-1.53$; $\mathrm{AA}$ versus $\mathrm{GG}$ : $\mathrm{OR}=0.77 ; 95 \% \mathrm{Cl}, 0.58-1.03$; dominant model: $\mathrm{OR}=1.16 ; 95 \% \mathrm{Cl}, 0.89-1.51$; and recessive model: $\mathrm{OR}=0.78 ; 95 \% \mathrm{Cl}, 0.59-1.04$, respectively).

Conclusion: Our results indicate that ATM D1853N polymorphism is not a risk factor for developing breast cancer.

\section{Background}

Ataxia-telangiectasia (A-T) is an autosomal recessive disorder that affects many parts of the body and leads to increased risk of malignancy, including breast cancer [1-3]. A-T is caused by mutations in the ataxia telangiectasia-mutated (ATM) [4]. ATM, a member of the phosphatidylinositol 3-kinase-like family, plays central roles in the repair of DNA double-strand breaks that was caused by a range of DNA-damaging agents such as ionizing radiation [5].

The ATM gene, located on chromosome 11q22-23 and consisting of 66 exons, has been reported to be involved in numerous damage repair signaling pathways and cell-cycle checkpoints $[4,6]$. Loss of heterozygosity in the region of the $A T M$ gene has been detected in

\footnotetext{
* Correspondence: zhanglin@scu.edu.cn

+ Contributed equally

'Laboratory of Molecular Translational Medicine, West China Second University Hospital, Sichuan University, Chengdu, Sichuan 610041, China Full list of author information is available at the end of the article
}

approximately $40 \%$ of human sporadic breast tumors [7-11]. Breast cancer patients with the combination of radiation treatment and an $A T M$ missense variant resulted in a shorter mean interval to develop a second tumor than patients without radiation treatment and ATM germline mutation [12]. Previously, some studies reported that female ATM-heterozygous carriers have an increased risk of breast cancer [1,13-18]. In contrast, some studies failed to find that ATM-heterozygous mutations were more frequent in breast cancer cases.

Recently, Mehdipour et al. reported that a common single nucleotide polymorphism ATM exon39 5557G > A (D1853N, rs1801516) may be considered as a predisposition factor for developing breast cancer, especially in cancer-prone pedigrees [19]. To date, a number of studies have been performed to investigate the association between the $A T M D 1853 \mathrm{~N}$ polymorphism and breast cancer risk, but the evidence regarding the role of $A T M$ as a genetic marker for breast cancer is
C Biomed Central

C 2010 Gao et al; licensee BioMed Central Ltd. This is an Open Access article distributed under the terms of the Creative Commons Attribution License (http://creativecommons.org/licenses/by/2.0), which permits unrestricted use, distribution, and reproduction in any medium, provided the original work is properly cited. 
conflicting. In order to provide stronger evidence for estimating the association, a meta-analysis was performed.

\section{Materials and methods}

\section{Eligible studies and data extraction}

We searched the articles using the following terms "ATM" and "breast cancer" and "polymorphism" or "variant" in PubMed and Embase databases (last search: 31 May, 2010). Additionally, we checked all relevant publications to retrieve the most eligible literatures.

The inclusion criteria were used for the literature selection: (a) articles about ATM D1853N polymorphism and breast cancer risk; (b) case-control studies; (c) sufficient published data for calculating odds ratios (ORs) and their corresponding 95\% confidence intervals (95\% CIs). The following information was collected independently by two investigators (Gao LB and Pan XM) from each study: first author's surname, year of publication, country, ethnicity, number of cases and controls with various genotypes, genotyping techniques, quality control for the genotyping methods, Hardy-Weinberg equilibrium (HWE) and minor allele frequency (MAF) in controls (Table 1).

\section{Statistical analysis}

The process of meta-analysis in the current study was performed as described previously in detail [20-22]. In brief, crude ORs and corresponding 95\% CIs were preformed to assess the association between ATM D1853N polymorphism and breast cancer risk. The pooled ORs were calculated for heterozygote comparison (GA versus $\mathrm{GG}$ ), homozygote comparison (AA versus GG), dominant model (GA/AA versus GG) and recessive model (AA versus GA/GG), respectively. The statistical heterogeneity among studies was checked by $Q$-test and $I^{2}$ statistics [23]. If the $P$ value greater than 0.10 for $Q$-test, indicating absence of heterogeneity, the fixed-effects model (the Mantel-Haenszel method) was used to calculate the pooled OR [24]; otherwise, the random-effects model (the DerSimonian and Laird method) was used [25]. Publication bias of literatures was estimated using Begg's funnel plot [26]. All statistical analyses were carried out with STATA software, version 10.0 (STATA Corp., College Station, TX).

\section{Results}

\section{Characteristics of studies}

Overall, nine studies involving 4,191 cases and 3,780 controls about ATM D1853N polymorphism and breast cancer susceptibility were available for this meta-analysis. The main characteristics of eligible studies are summarized in Table 1. There were six studies of European populations, two studies of South American populations, and one study of mixed population that included more than one ethnic descent. Several genotyping methods were used, including polymerase chain reaction-restriction fragment length polymorphism (PCR-RFLP), denatured high performance liquid chromatography (DHPLC), allele-specific oligonucleotide (ASO), PCRsingle strand conformation polymorphism (PCR-SSCP), conformation sensitive gel electrophoresis (CSGE), TaqMan, and sequencing. Approximately 67\% (6/9) of these studies described quality control for the genotyping assay. The genotype distributions in the controls of all studies were consistent with Hardy-Weinberg equilibrium except for one study [27].

\section{Main results}

The main results of this meta-analysis are shown in Table 2. Overall, no significant association between the ATM D1853N polymorphism and breast cancer risk was observed. After subgroup analyses according to ethnicity, significantly increased risk was observed in South

Table 1 Characteristics of literatures included in the meta-analysis

\begin{tabular}{|c|c|c|c|c|c|c|c|c|c|c|c|}
\hline \multirow[t]{3}{*}{ References } & \multirow[t]{3}{*}{ Year } & \multirow[t]{3}{*}{ Country } & \multirow[t]{3}{*}{ Ethnicity } & \multicolumn{6}{|c|}{ Genotype distribution } & \multirow[t]{3}{*}{ HWE (controls) } & \multirow[t]{3}{*}{ MAF } \\
\hline & & & & \multicolumn{3}{|l|}{ case } & \multicolumn{3}{|c|}{ control } & & \\
\hline & & & & $\overline{\mathrm{GG}}$ & GA & AA & GG & GA & AA & & \\
\hline Angele [30] & 2003 & France & European & 192 & 56 & 6 & 240 & 65 & 7 & Yes & 0.13 \\
\hline Buchholz [31] & 2004 & USA & Mixed & 39 & 17 & 2 & 394 & 119 & 15 & Yes & 0.14 \\
\hline Dork [32] & 2001 & Germany & European & 753 & 235 & 12 & 422 & 74 & 4 & Yes & 0.08 \\
\hline Gonzalez-Hormazabal [29] & 2008 & Chile & South American & 100 & 26 & 0 & 174 & 26 & 0 & Yes & 0.07 \\
\hline Heikkinen [33] & 2005 & Finland & European & 68 & 44 & 9 & 174 & 109 & 23 & Yes & 0.25 \\
\hline Renwick [34] & 2006 & UK & European & 339 & 98 & 6 & 371 & 131 & 19 & Yes & 0.16 \\
\hline Schrauder [35] & 2008 & Germany & European & 406 & 99 & 9 & 369 & 129 & 13 & Yes & 0.15 \\
\hline Tapia [27] & 2008 & Chile & South American & 74 & 19 & 1 & 183 & 15 & 2 & No & 0.05 \\
\hline Tommiska [36] & 2006 & Finland & European & 954 & 561 & 66 & 404 & 260 & 38 & Yes & 0.24 \\
\hline
\end{tabular}

HWE, Hardy-Weinberg equilibrium

MAF, minor allele frequency 
Table 2 Main results of pooled ORs in the meta-analysis

\begin{tabular}{|c|c|c|c|c|c|c|c|c|c|c|}
\hline & \multirow[t]{2}{*}{$\mathrm{n}^{\mathrm{a}}$} & \multirow[t]{2}{*}{ Cases/controls } & \multicolumn{2}{|l|}{ GA versus GG } & \multicolumn{2}{|l|}{$A A$ versus $G G$} & \multicolumn{2}{|c|}{$\begin{array}{l}\text { GA/AA versus GG } \\
\text { (dominant) }\end{array}$} & \multicolumn{2}{|c|}{$\begin{array}{l}\text { AA versus GA/GG } \\
\text { (recessive) }\end{array}$} \\
\hline & & & OR $(95 \% \mathrm{Cl})$ & $P^{b}$ & OR $(95 \% \mathrm{Cl})$ & $P^{b}$ & OR $(95 \% \mathrm{Cl})$ & $P^{b}$ & OR $(95 \% \mathrm{Cl})$ & $P^{b}$ \\
\hline Total & 9 & $4,191 / 3,780$ & $1.18(0.90-1.53)$ & $<0.001$ & $0.77(0.58-1.03)$ & 0.50 & $1.16(0.89-1.51)$ & $<0.001$ & $0.78(0.59-1.04)$ & 0.66 \\
\hline \multicolumn{11}{|l|}{ Ethnicity } \\
\hline European & 6 & $3,913 / 2,852$ & $1.00(0.77-1.31)$ & $<0.001$ & $0.75(0.56-1.01)$ & 0.34 & $0.98(0.75-1.29)$ & $<0.001$ & $0.77(0.57-1.02)$ & 0.46 \\
\hline South American & 2 & $220 / 400$ & $2.19(1.38-3.47)$ & 0.22 & $1.24(0.11-13.84)$ & - & $2.15(1.37-3.38)$ & 0.27 & $1.07(0.10-11.89)$ & - \\
\hline Mixed & 1 & $58 / 528$ & $1.44(0.79-2.64)$ & - & $1.35(0.30-6.11)$ & - & $1.43(0.80-2.56)$ & - & $1.22(0.27-5.48)$ & - \\
\hline
\end{tabular}

${ }^{a}$ Number of comparisons

${ }^{b} P$ value of Q-test for heterogeneity test. Random-effects model was used if the $P$ value $<0.10$; otherwise, fixed-effects model was used

American population (GA versus GG: OR $=2.19$; $95 \%$ CI, 1.38-3.47; and dominant model: $\mathrm{OR}=2.15$; $95 \% \mathrm{CI}$, 1.37-3.38, respectively) but not in European and mixed populations.

\section{Publication bias}

Begg's funnel plot was used to identify the potential publication bias of literatures on breast cancer, and the results did not show any evidence of publication bias in any comparison model $(P>0.05)$.

\section{Discussion}

Previous studies have inconclusive results about the association between ATM D1853N polymorphism and breast cancer risk, which might be caused by relatively small sample size in a single study. Meta-analysis offers a rational and helpful way to solve this practical problem by combination the findings from independent studies. In the current meta-analysis, we cumulated the data from nine case-control studies to explore the association between $A T M$ D $1853 \mathrm{~N}$ polymorphism and breast cancer risk. No significant association between this polymorphism and breast cancer risk was observed in the overall study populations. Our result was consistent with the finding from a previous meta-analysis showing that another polymorphism of ATM (S49C, rs1800054) was not significantly associated with breast cancer susceptibility [28]. This finding indicates that the $A T M$ D $1853 \mathrm{~N}$ polymorphism is not a risk factor for developing breast cancer, although a significantly increased risk of breast cancer in ATM-heterozygous carriers has been reported [1,13-18].

After subgroup analyses according to ethnicity, we found that the ATM D1853N polymorphism was associated with a significantly increased risk of breast cancer in South American population (heterozygote comparison and dominant model) but not in European and mixed populations. The reason for these discrepancies is not very clear. There are, however, some possible reasons. Firstly, the ATM D1853N polymorphism may present with different frequencies in different populations and as a result may be associated with different degrees of breast cancer risk among different ethnic populations. Secondly, the genotype distribution in the controls of a South American study was departed from Hardy-Weinberg equilibrium [27], indicating that there was a high risk of selection bias because the controls may not be representative of the general population very well. Thirdly, the positive association might have occurred by chance due to the insufficient statistical power with only two South American studies eligible in this meta-analysis $[27,29]$. Therefore, additional studies with larger sample size are of great importance to clarify this finding.

Some limitations of this meta-analysis should be taken into consideration. On the one hand, the numbers of cases and controls analyzed for D1853N (rs1801516) found in the literature is still very small and might not precisely answer the given question. Especially, for some subgroup analyses, the statistical power is so low that caution should be taken in interpreting these results, even though positive association was found in South American population. On the other hand, data were not stratified by age at menarche, number of full-term pregnancies, menopausal status, and other suspected factors due to absence of available information.

In conclusion, the overall outcomes of this meta-analysis have shown that the ATM D1853N polymorphism is not associated with breast cancer risk, indicating that this polymorphism is not an independent risk factor for the development of breast cancer. Well-designed, unbiased studies with a wider spectrum of subjects should be of great value to explore other potential risk factors.

\section{Acknowledgements}

This work was supported by the National Natural Science Foundation of China (No. 30801317), and Science \& Technology Pillar Program of Sichuan Province (No. 2010SZ0122).

\section{Author details}

'Laboratory of Molecular Translational Medicine, West China Second University Hospital, Sichuan University, Chengdu, Sichuan 610041, China. 
${ }^{2}$ Department of Forensic Pathology, Henan University of Science and Technology, Luoyang, Henan 471003, China. ${ }^{3}$ Department of Forensic Biology, West China School of Preclinical and Forensic Medicine, Sichuan University, Chengdu, Sichuan 610041, China. ${ }^{4}$ Department of Immunology, West China School of Preclinical and Forensic Medicine, Sichuan University, Chengdu, Sichuan 610041, China. ${ }^{5}$ Department of Cardiology, West China Hospital of Sichuan University, Chengdu, Sichuan, 610041 China.

${ }^{6}$ Department of Pathology, College of Preclinical Medicine, Dali University, Dali, Yunnan, 671000, China.

\section{Authors' contributions}

GLB, PXM, and Zhang L designed the study, and wrote the manuscript; $S H$, $W X$, and RL performed data acquisition; LLJ performed quality control of data; LWB, LML, and YWZ performed statistical analysis and interpretation. All authors read and approved the final manuscript.

\section{Competing interests}

The authors declare that they have no competing interests.

Received: 14 August 2010 Accepted: 27 August 2010

Published: 27 August 2010

\section{References}

1. Swift M, Reitnauer PJ, Morrell D, Chase CL: Breast and other cancers in families with ataxia-telangiectasia. N Engl J Med 1987, 316:1289-1294.

2. Chen J, Birkholtz GG, Lindblom P, Rubio C, Lindblom A: The role of ataxiatelangiectasia heterozygotes in familial breast cancer. Cancer Res 1998, 58:1376-1379.

3. Borresen AL, Andersen TI, Tretli S, Heiberg A, Moller P: Breast cancer and other cancers in Norwegian families with ataxia-telangiectasia. Genes Chromosomes Cancer 1990, 2:339-340.

4. Savitsky K, Bar-Shira A, Gilad S, Rotman G, Ziv Y, Vanagaite L, Tagle DA, Smith S, Uziel T, Sfez S, Ashkenazi M, Pecker I, Frydman M, Harnik R, Patanjali SR, Simmons A, Clines GA, Sartiel A, Gatti RA, Chessa L, Sanal O, Lavin MF, Jaspers NG, Taylor AM, Arlett CF, Miki T, Weissman SM, Lovett M, Collins FS, Shiloh Y: A single ataxia telangiectasia gene with a product similar to PI-3 kinase. Science 1995, 268:1749-1753.

5. Abraham RT: PI 3-kinase related kinases: 'big' players in stress-induced signaling pathways. DNA Repair (Amst) 2004, 3:883-887.

6. Shiloh Y, Kastan MB: ATM: genome stability, neuronal development, and cancer cross paths. Adv Cancer Res 2001, 83:209-254.

7. Angele $S$, Hall J: The ATM gene and breast cancer: is it really a risk factor? Mutat Res 2000, 462:167-178.

8. Negrini M, Rasio D, Hampton GM, Sabbioni S, Rattan S, Carter SL, Rosenberg AL, Schwartz GF, Shiloh Y, Cavenee WK, Croce CM: Definition and refinement of chromosome 11 regions of loss of heterozygosity in breast cancer: identification of a new region at 11q23.3. Cancer Res 1995, 55:3003-3007.

9. Laake K, Launonen V, Niederacher D, Gudlaugsdottir S, Seitz S, Rio P, Champeme MH, Bieche I, Birnbaum D, White G, Sztan M, Sever N, Plummer S, Osorio A, Broeks A, Huusko P, Spurr N, Borg A, CletonJansen AM, van't Veer L, Benitez J, Casey G, Peterlin B, Olah E, BorresenDale AL: Loss of heterozygosity at 11q23.1 and survival in breast cancer: results of a large European study. Breast Cancer Somatic Genetics Consortium. Genes Chromosomes Cancer 1999, 25:212-221.

10. Hampton GM, Mannermaa A, Winqvist R, Alavaikko M, Blanco G, Taskinen PJ, Kiviniemi H, Newsham I, Cavenee WK, Evans GA: Loss of heterozygosity in sporadic human breast carcinoma: a common region between 11q22 and 11q23.3. Cancer Res 1994, 54:4586-4589.

11. Carter SL, Negrini M, Baffa R, Gillum DR, Rosenberg AL, Schwartz GF, Croce CM: Loss of heterozygosity at 11q22-q23 in breast cancer. Cancer Res 1994, 54:6270-6274.

12. Broeks A, Braaf LM, Huseinovic A, Schmidt MK, Russell NS, van Leeuwen FE, Hogervorst FB, van't Veer LJ: The spectrum of ATM missense variants and their contribution to contralateral breast cancer. Breast Cancer Res Treat 2008, 107:243-248.

13. Swift M, Morrell D, Massey RB, Chase CL: Incidence of cancer in 161 families affected by ataxia-telangiectasia. N Engl J Med 1991, 325:1831-1836.

14. Easton DF: Cancer risks in A-T heterozygotes. Int J Radiat Biol 1994, 66 S177-182.
15. Inskip HM, Kinlen LJ, Taylor AM, Woods CG, Arlett CF: Risk of breast cancer and other cancers in heterozygotes for ataxia-telangiectasia. $\mathrm{Br} J$ Cancer 1999, 79:1304-1307.

16. Athma P, Rappaport R, Swift M: Molecular genotyping shows that ataxiatelangiectasia heterozygotes are predisposed to breast cancer. Cancer Genet Cytogenet 1996, 92:130-134.

17. Broeks A, Urbanus JH, Floore AN, Dahler EC, Klijn JG, Rutgers EJ, Devilee $P$, Russell NS, van Leeuwen FE, van't Veer LJ: ATM-heterozygous germline mutations contribute to breast cancer-susceptibility. Am J Hum Genet 2000, 66:494-500.

18. Milne RL: Variants in the ATM gene and breast cancer susceptibility. Genome Medicine 2009, 1.

19. Mehdipour P, Mahdavi M, Mohammadi-AsI J, Atri M: Importance of ATM gene as a susceptible trait: predisposition role of $\mathrm{D} 1853 \mathrm{~N}$ polymorphism in breast cancer. Medical Oncology 2010, 1-5.

20. Gao LB, Pan XM, Jia J, Liang WB, Rao L, Xue H, Zhu Y, Li SL, Lv ML, Deng W, Chen TY, Wei YG, Zhang L: IL-8 -251A/T polymorphism is associated with decreased cancer risk among population-based studies: evidence from a meta-analysis. Eur J Cancer 2010, 46:1333-1343.

21. Gao LB, Bai P, Pan XM, Jia J, Li LJ, Liang WB, Tang M, Zhang LS, Wei YG, Zhang $L$ : The association between two polymorphisms in pre-miRNAs and breast cancer risk: a meta-analysis. Breast Cancer Res Treat 2010.

22. Gao LB, Pan XM, Li LJ, Liang WB, Zhu Y, Zhang LS, Wei YG, Tang M, Zhang L: RAD51 135G/C polymorphism and breast cancer risk: a metaanalysis from 21 studies. Breast Cancer Res Treat 2010.

23. Higgins JP, Thompson SG: Quantifying heterogeneity in a meta-analysis. Stat Med 2002, 21:1539-1558.

24. Mantel N, Haenszel W: Statistical aspects of the analysis of data from retrospective studies of disease. J Natl Cancer Inst 1959, 22:719-748.

25. DerSimonian R, Laird N: Meta-analysis in clinical trials. Control Clin Trials 1986, 7:177-188.

26. Egger M, Davey Smith G, Schneider M, Minder C: Bias in meta-analysis detected by a simple, graphical test. BMJ 1997, 315:629-634.

27. Tapia T, Sanchez A, Vallejos M, Alvarez C, Moraga M, Smalley S, Camus M, Alvarez M, Carvallo P: ATM allelic variants associated to hereditary breast cancer in 94 Chilean women: susceptibility or ethnic influences? Breast Cancer Res Treat 2008, 107:281-288.

28. Cox A, Dunning AM, Garcia-Closas M, Balasubramanian S, Reed MW, Pooley KA, Scollen S, Baynes C, Ponder BA, Chanock S, Lissowska J, Brinton L, Peplonska B, Southey MC, Hopper JL, McCredie MR, Giles GG, Fletcher O, Johnson N, dos Santos Silva I, Gibson L, Bojesen SE, Nordestgaard BG, Axelsson CK, Torres D, Hamann U, Justenhoven C, Brauch H, Chang-Claude J, Kropp S, Risch A, Wang-Gohrke S, Schurmann P, Bogdanova N, Dork T, Fagerholm R, Aaltonen K, Blomqvist C, Nevanlinna H, Seal S, Renwick A, Stratton MR, Rahman N, Sangrajrang S, Hughes D, Odefrey F, Brennan P, Spurdle AB, Chenevix-Trench G, Beesley J, Mannermaa A, Hartikainen J, Kataja V, Kosma VM, Couch FJ, Olson JE, Goode EL, Broeks A, Schmidt MK, Hogervorst FB, Van't Veer LJ, Kang D, Yoo KY, Noh DY, Ahn SH, Wedren S, Hall P, Low YL, Liu J, Milne RL, Ribas G, Gonzalez-Neira A, Benitez J, Sigurdson AJ, Stredrick DL, Alexander BH, Struewing JP, Pharoah PD, Easton DF: A common coding variant in CASP8 is associated with breast cancer risk. Nat Genet 2007, 39:352-358.

29. Gonzalez-Hormazabal P, Bravo T, Blanco R, Valenzuela CY, Gomez F, Waugh E, Peralta O, Ortuzar W, Reyes JM, Jara L: Association of common ATM variants with familial breast cancer in a South American population. BMC Cancer 2008, 8:117.

30. Angele $S$, Romestaing P, Moullan N, Vuillaume M, Chapot B, Friesen M, Jongmans W, Cox DG, Pisani P, Gerard JP, Hall J: ATM haplotypes and cellular response to DNA damage: association with breast cancer risk and clinical radiosensitivity. Cancer Res 2003, 63:8717-8725.

31. Buchholz TA, Weil MM, Ashorn CL, Strom EA, Sigurdson A, Bondy M, Chakraborty R, Cox JD, McNeese MD, Story MD: A Ser49Cys Variant in the Ataxia Telangiectasia, Mutated, Gene that Is More Common in Patients with Breast Carcinoma Compared with Population Controls. Cancer 2004, 100:1345-1351.

32. Dork T, Bendix R, Bremer M, Rades D, Klopper K, Nicke M, Skawran B, Hector A, Yamini P, Steinmann D, Weise S, Stuhrmann M, Karstens JH: Spectrum of ATM gene mutations in a hospital-based series of unselected breast cancer patients. Cancer Res 2001, 61:7608-7615. 
33. Heikkinen K, Rapakko K, Karppinen SM, Erkko H, Nieminen P, Winqvist R: Association of common ATM polymorphism with bilateral breast cancer. Int J Cancer 2005, 116:69-72.

34. Renwick A, Thompson D, Seal S, Kelly P, Chagtai T, Ahmed M, North B, Jayatilake H, Barfoot R, Spanova K, McGuffog L, Evans DG, Eccles D, Easton DF, Stratton MR, Rahman N: ATM mutations that cause ataxiatelangiectasia are breast cancer susceptibility alleles. Nat Genet 2006, 38:873-875.

35. Schrauder M, Frank S, Strissel PL, Lux MP, Bani MR, Rauh C, Sieber CC Heusinger K, Hartmann A, Schulz-Wendtland R, Strick R, Beckmann MW, Fasching PA: Single nucleotide polymorphism D1853N of the ATM gene may alter the risk for breast cancer. J Cancer Res Clin Oncol 2008, 134:873-882.

36. Tommiska J, Jansen L, Kilpivaara O, Edvardsen H, Kristensen V, Tamminen A, Aittomaki K, Blomqvist C, Borresen-Dale AL, Nevanlinna H: ATM variants and cancer risk in breast cancer patients from Southern Finland. $B M C$ Cancer 2006, 6:209.

doi:10.1186/1756-9966-29-117

Cite this article as: Gao et al:: The association between ATM D1853N

polymorphism and breast cancer susceptibility: a meta-analysis. Journal of Experimental \& Clinical Cancer Research 2010 29:117.

\section{Submit your next manuscript to BioMed Central} and take full advantage of:

- Convenient online submission

- Thorough peer review

- No space constraints or color figure charges

- Immediate publication on acceptance

- Inclusion in PubMed, CAS, Scopus and Google Scholar

- Research which is freely available for redistribution

Submit your manuscript at www.biomedcentral.com/submit 